MRN

29,10

604

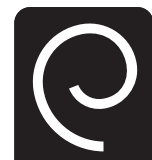

Emerald

Management Research News

Vol. 29 No. 10, 2006

pp. $604-617$

(C) Emerald Group Publishing Limited $0140-9174$

DOI $10.1108 / 01409170610712317$

\section{Project management elements as strategic assets: preliminary findings}

\author{
Kam Jugdev
}

Project Management and Strategy, Centre for Innovative Management, Athabasca University, Alberta, Canada and Schulich School of Engineering,

University of Calgary, Calgary, Canada, and

Gita Mathur

Department of Organization and Management, College of Business, San José State University, One Washington Square, San José, California, USA

\begin{abstract}
Purpose - To examine project management assets and to explore the link between these and the achievement of competitive advantage from the project management process through it being valuable, rare, inimitable, and having organizational support.

Design/methodology/approach - An online survey with North American Project Management Institute ${ }^{\circledR}$ members was conducted. Exploratory factor analysis was used to identify tangible and intangible elements of project management and the achievement of competitive characteristics of the project management process.

Findings - Six factors were extracted that comprised project management assets and three factors that comprised the competitive characteristics of the project management process.

Research limitations/implications - This was an exploratory study. It is expected to further develop the instrument, refine the model and constructs, and test it with a larger sample.

Practical implications - This study highlights the importance of developing intangible project management assets to achieve competitive advantage from the process.

Originality/value - Few papers have used the resource based view lens and applied it to project management. This paper contributes to the literature on the resource based view of the firm and to an improved understanding of project management as a source of competitive advantage.

Keywords Competitive advantage, Project management, Factor analysis, Resource management, Strategic management

Paper type Research paper
\end{abstract}

\section{Introduction}

The resource based view of the firm examines competitive advantage in terms of a company's resources, both tangible and intangible. Companies have many resources (e.g. human, financial, organizational, physical, and technological), but few are considered strategic. Strategic resources (assets) contribute to a firm's competitive position and tend to be knowledge-based (Amit and Schoemaker, 1993). Strategic resources are valuable (provide economic value), rare (unique), inimitable (difficult to copy), and involve organizational support (management support, processes, and systems): VRIO (Barney, 2002; Barney, 1991). Both value and rarity are required for a temporary competitive advantage. Value, rarity, and inimitability are required for a sustained competitive advantage (Barney, 1998), and, as a company transitions from

This study was supported by Athabasca University, San José State University, and a grant from the Social Sciences and Research Council of Canada. The authors would like to acknowledge Dr Tak Fung for his expertise in statistical analysis, Dr Lisa LaFramboise for her editorial services, the study participants, and the reviewers for their helpful comments. 
competitive parity to a sustained competitive advantage, there is increasing evidence of organizational support (Barney, 1998).

While companies are increasingly focusing on the project management process to improve business results, little research has been done to fully understand how project management contributes to competitive advantage (DeFillippi and Arthur, 1998). It is therefore, crucial that the discipline develop analytical instruments to enable us to understand how different project management elements contribute to competitive advantage. This paper reports on the preliminary findings of the use of a survey instrument that draws on the VRIO framework to examine the factors that comprise project management assets.

The sections that follow include the literature review, presentation of the study methodology, discussion of findings, conclusions, limitations, and the next steps in the ongoing research program.

\section{Literature review}

Strategic assets (e.g. intellectual property rights, reputation, brand, culture, and tacit knowledge) contribute to a firm's competitive advantage. These resources involve codified and tacit knowledge (Eisenhardt and Santos, 2000; Kaplan et al., 2001; Kogut, 2000; Nonaka, 1994) embedded in a company's unique skills, knowledge, and resources (Rumelt et al., 1994; Foss, 1997). The resource based view and Barney's VRIO framework have been widely used in empirical studies on strategic assets (Barney, 1998; Ray et al., 2004; Zahra and Nielsen, 2002; Lopez, 2001; Castanias and Helfat, 2001; Wiggins and Ruefli, 2002; Montealegre, 2002). In 2005, the Academy of Management indicated that over 200 academic papers were published using the resource based view (AoM, 2005). However, few studies of project management use this perspective (DeFillippi and Arthur, 1998).

As a discipline, project management stems from engineering, decision sciences, and operations management and currently draws from management theory for its theoretical foundation (Packendorff, 1995; Koskela and Howell, 2002). Project management is a set of processes applied to a project to deliver a product, or service (Project Management Institute, 2004). Its practices are based on tangible (concrete and codified) and intangible (tacit) assets (Fernie et al., 2003; DeFillippi and Arthur, 1998). Some distinguish between codified and tacit knowledge by labeling them "know-what" and "know-how" (Nonaka, 1994). Tacit knowledge is shared informally through social exchanges, and is embedded in a firm's culture. To date, most of the project management literature has focused on the codified knowledge and tangible assets shared through project management (Ulri and Ulri, 2000; Kloppenborg and Opfer, 2002). The intangible dimension warrants further study.

Some of the literature promotes project management maturity models (which assess tangible assets) as sources of competitive advantage (Ibbs and Kwak, 2000; ESIInternational, 2001; Hartman, 2000; MicroFrame, 2001). Evidence that maturity models improve a company's return on investment is weak, however, and the models do not address intangible assets (Jugdev and Thomas, 2002).

Literature on knowledge management involves formal and informal knowledgesharing practices. Knowledge is inimitable because it is socially complex and causally ambiguous (Barney, 1999; Mata et al., 1995). Project teams often share knowledge through communities of practice (Lesser and Storck, 2001). The project management literature review revealed few empirical studies on project management as a strategic asset (DeFillippi and Arthur, 1998), and there are few empirical studies 
MRN

29,10

606

on knowledge management in the project management context (Fernie et al., 2003). This study makes a contribution to the growing body of empirical works on strategic assets.

\section{Conceptual model}

Project management's potential as a source of competitive advantage will depend on the extent to which a company develops project management according to VRIO characteristics. An investment in tangible project management assets primarily enhances the valuable and organizational support dimensions (Barney, 2002). As such assets are not rare (e.g. unless the organization owns the copyright or trademark), competing firms can copy them so these investments do not improve a firm's competitive positions. However, intangible assets can be valuable, rare, and inimitable, with organizational support (Barney, 2002). Companies often do not recognize the value of intangible assets.

We propose a conceptual model (Figure 1) to link the achievement of VRIO characteristics of the project management process (dependent variable) to tangible and intangible assets (independent variables). Conceptually, this model shows latent (unobservable) variables. These latent variables are split into tangible and intangible assets drawing on the literature that discusses the resource based view of the firm (Teece et al., 1997; Castanias and Helfat, 1991; Chakraborty, 1997; Barney and Zajac, 1994; Kogut and Zander, 1993; Hawawini et al., 2002).

Further development came from a mixed methods study involving in-depth interviews with 67 project managers at four international companies (Jugdev, 2003;

Figure 1.

Conceptual model linking tangible and intangible assets and VRIO characteristics of the project management process

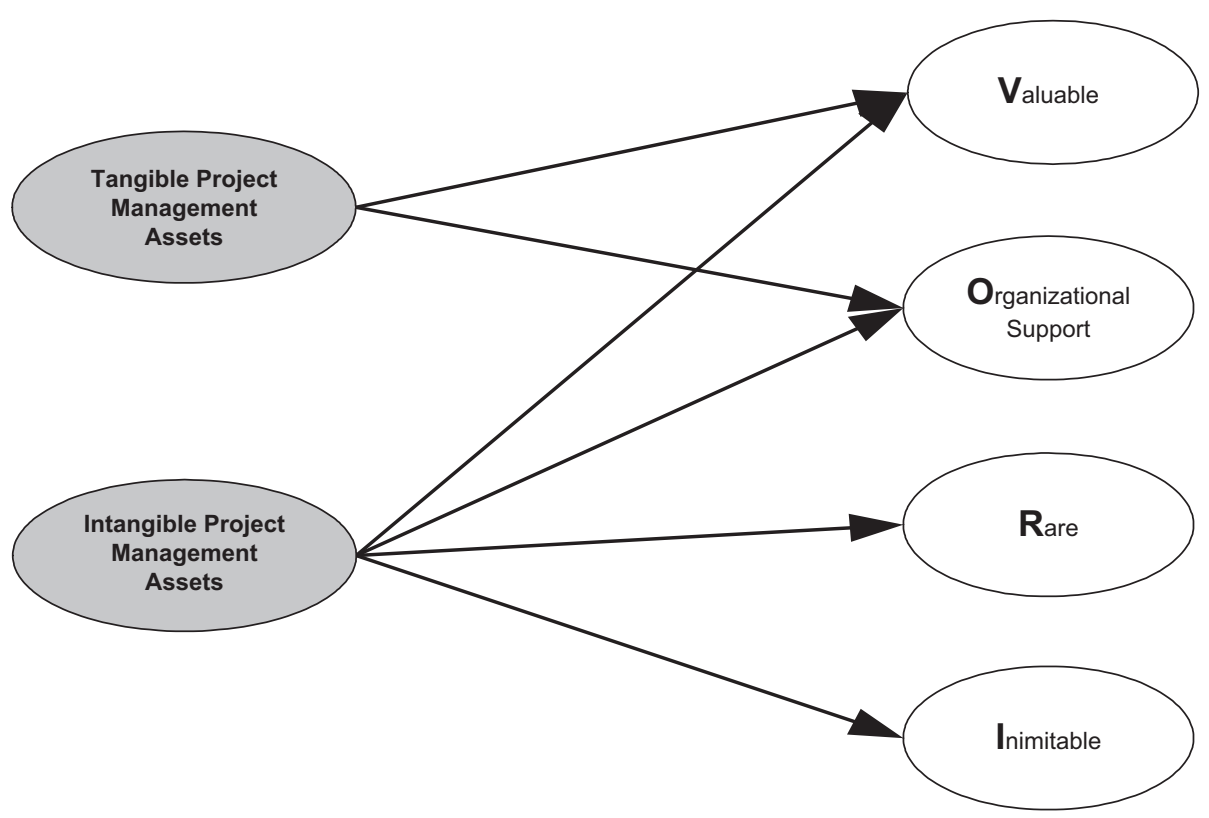


2005). This study provided additional understanding of the VRIO constructs and led to the development of an online survey tool.

This paper reports on the findings from a factor analysis of data gathered using the survey tool to further explore the factors that constitute the independent and dependent variables. The linkages between the independent and dependent variables are beyond the scope of this study. The development of a path model based on the data reported in this paper will be addressed in future research. This paper contributes to the understanding of project management as a source of competitive advantage. It helps heighten awareness of the importance of intangible assets in addition to tangible assets in project management.

\section{Methodology}

Our survey design closely followed the format recommended by experts (Dillman $e t$ al., 1993; Fowler, 1992; Couper et al., 2001). We developed items for each latent variable, and created a survey instrument consisting of 80 questions, 12 demographic questions, and an open-ended question for additional input. We used a 7-point Likert scale with the anchors being "Strongly Agree" and "Strongly Disagree," with a "Not Applicable" category where relevant. We used multiple-item measures and minimized retrospective bias by focusing questions on the past year. To improve validity, the survey was pretested with 10 academic colleagues and feedback was incorporated in item wording and list of questions.

We used a large-scale internet survey design because it is faster and more costeffective than a mail-out survey, and it helps reduce non-response errors (Couper, 2000). Stamped return envelopes were sent to study participants to help identify the sampling frame and response rate. Copies of the instrument and methodology details are available upon request. Our random sample was generated from the Project Management Institute's ${ }^{\circledR}$ mailing list $(n=2,000 ; 1,500$ Americans, and 500 Canadians, which represents the institute's membership and, drawing from all of North America, controls for country-specific factors). Participants ranged from project managers to executives. The response rate was 10.1 per cent (202 participants). Our sample size was fair (Tabachnick and Fidell, 2000) for an exploratory factor analysis because the ratio of sample size (202) to the number of variables (80) was less than 5:1.

We used SPSS ${ }^{\circledR}$ v. 13 to conduct exploratory factor analysis and extract factors representing project management assets and the VRIO characteristics of the project management process. We used the principal components extraction method with Varimax (variance maximizing) rotation. This extraction method is widely used, understood, and conforms to the factor analytic model in which common variance is analyzed with the unique and error variances removed (Tabachnick and Fidell, 2000). We used 0.40 as a cutoff to identify items with the highest loadings for inclusion with a factor (Conway and Huffcutt, 2003). Eigenvalues over one were used to extract reliable factors.

Cronbach's alpha measures how well a set of items measures a single unidimensional latent construct. A reliability coefficient of 0.70 or higher is acceptable in the social sciences (Nunnally, 1978). We used this test to assess the internal consistency of the items within each construct. In addition, we looked for factors consisting of three or more items. Our starting model had eight factors for the independent variables and five factors for the dependent variable. We extracted six factors for the independent variables and three factors for the dependent variable based on the requirement of three or more items. 
MRN

29,10

608
Table I.

Rotated component matrix of independent variables

\section{Findings}

The exploratory factor analysis yielded six factors that represented the independent variables, project management assets. Table I shows the rotated component matrix for the independent variables.

The six factors were labeled to reflect items that define them. Entries are bolded to clarify which items load on a particular factor in Table I. Factors 1, 3, and 4, below (and

Items constituting independent variables

1

2

3

4

5

6

q1.3 We use portfolio/program management practices to effectively manage groups of projects within....

q3.9 We use project management to

optimize business decisions

$0.691 \quad 0.311$

q1.2 We have an effective project

management Office. A project management

office helps organization.

q3.10 When it comes to project

management,we are the best of breed

q3.8 We use project management to

understand how 1 project impacts on other

projects

q3.1 We try to improve our project

management practices according to a

project management maturity framework

q3.11 We use project management to make organizational decisions for the future

q1.4 We effectively use project management tools and techniques to manage projects

q1.1 We have a good project management methodology

q1.6 Our project management tools are integrated with our enterprise systems q3.5 Our project management program is based on organization standards q3.6 We use project management to address efficiency issues

q3.7 We use project management to

address effectiveness issues

q1.5 Our project management tools meet our project needs

0.675

0.378

$0.627 \quad 0.326$

$\begin{array}{lll}0.601 & 0.339 & 0.358\end{array}$

$\begin{array}{lll}0.598 & 0.407 & 0.312\end{array}$

$\begin{array}{lll}0.589 & 0.358 & 0.336\end{array}$

$\begin{array}{lll}0.574 & 0.428 & 0.373\end{array}$

$0.569 \quad 0.478$

$\begin{array}{lll}0.569 & 0.359 & 0.315\end{array}$

$0.556 \quad 0.325$

0.550

0.524

$0.331 \quad 0.368$

0.798

0.787

0.756

$0.386 \quad 0.692$ 
Items constituting independent variables

q5.2 At my organization we share project management knowledge by showing each other how we do things in project management q5.4 We explore project management topics among ourselves through informal get togethers

q7.3 We often share know-how through "war stories" about our project experiences q5.1 Our project management mentoring program helps us be more effective on projects

q7.4 We regularly share project lessons learned in a face-to-face manner q7.1 Our community of practice helps us be more effective in project management q8.4 My organization encourages us to explore project management topics with colleagues at other organization q2.1 My organization invests in developing project manager competences in tools and techniques

q2.4 There is support for project management training q2.2 My organization invests in developing project manager competences in leadership q2.3 My organization invests in developing project manager competences in interpersonal skills q2.6 The organization supports project management certification management professionals

q3.3 Management supports project management at my organization q2.5 We have a career path for those in project management positions q3.4 We use project management consistently on projects at my organization q4.3 We have adequate organizational systems to share project management knowledge

q4.4 We have adequate organizational processes to share project management knowledge

q4.2 We share project management knowledge through databases q4.5 We regularly use our organizational systems and processes to share project management knowledge q4.1 We share project management knowledge through our internet
1

2

3

4

5

6

0.328

0.681

0.643

0.641

0.602

0.582

$0.304 \quad 0.533$

0.440

$-0.452 \quad-0.313$

$-0.318$

0.843

0.825

0.815

0.808

0.693

0.308

0.348

0.626

0.592

0.397

$0.484 \quad 0.342$

0.805

0.308

0.794

0.791

0.747

0.738 


\section{MRN \\ 29,10}

610
Items constituting independent variables

q7.6 We have project management best practice databases to help us with our projects

q7.2 We share project management knowledge through documented practices at my organization, e.g.

q9.1 Know-how is not important at my organization q9.2 Know-how is not valued at my organization

q8.5 Project management knowledge is not shared at my organization because knowledge is power q8.7 Ongoing learning is not a concept that my organization supports q3.2 Our project management practices are based on "accidental" processes, i.e. unplanned or ad hoc processes q8.3 Knowledge sharing is limited to within departments and rarely takes place across the organization q8.6 Project management knowledge is not shared at my organization because it takes too much time q8.2 Knowledge sharing is limited to within project teams at my organization
0.308 0.677

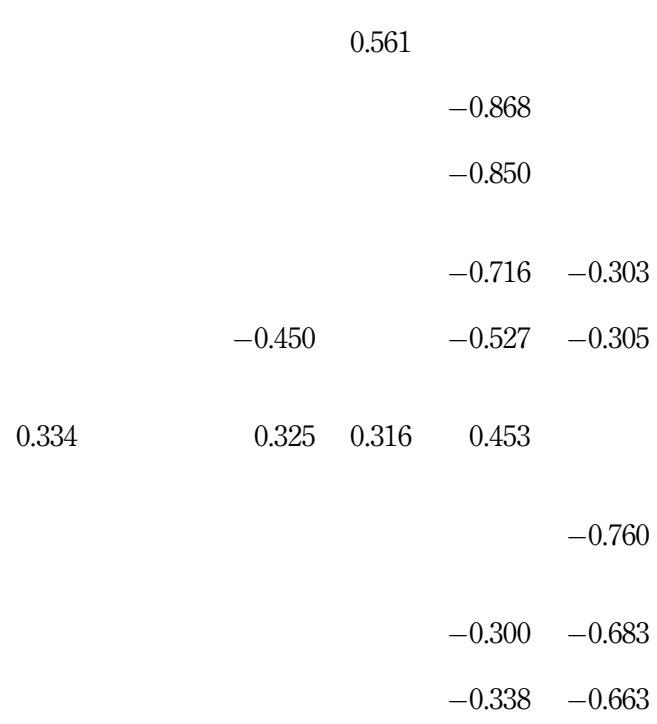

Notes: Extraction method: principal component analysis; Rotation method: varimax with kaiser normalization; Rotation converged in 13 iterations; Bolded entries in a column indicate items that Table I. load on the particular factor; Reverse coding was used on item q8.4, q3.2

in Table I), represent tangible project management assets; factors 2, 5, and 6 represent intangible project management assets:

(1) The latent construct of project management maturity (tangible project management asset) consisted of 14 items and had a Cronbach's Alpha of 0.953.

(2) The latent construct of sharing know-how (intangible project management asset) consisted of 11 items and had a Cronbach's Alpha of 0.867.

(3) The latent construct of training and development (tangible project management asset) consisted of eight items and had a Cronbach's Alpha of 0.931 .

(4) The latent construct of sharing know what (tangible project management asset) consisted of seven items and had a Cronbach's Alpha of 0.939 .

(5) The latent construct of undervalued sharing of know-how (intangible project management asset) consisted of five items and had a Cronbach's Alpha of 0.773 .

(6) The latent construct of undervalued sharing of knowledge (intangible project management asset) consisted of three items and had a Cronbach's Alpha of 0.463 (while this factor might be viewed with caution because of the low 
Cronbach's alpha, we retained this factor for ongoing analysis because it had three items loading on it).

The six factors extracted as project management assets represent 67.76 per cent of the total variance of the original variables, which is quite acceptable for a factor analysis. The two factors on undervalued sharing are expected to negatively influence the dependent variable while the other four asset factors are expected to positively influence the dependent variable.

Project management maturity was the first factor that emerged, and it reflected the use of tangible project management practices such as a project management office, tools and techniques, methodology, standards, and processes, as well as the use of program and portfolio management practices and efficient and effective practices. This factor explains 14.11 per cent of the total variance of the original variables. This result shows the breadth of tangible project management assets as well as how widely used these assets are in practice.

The sharing know-how factor (an intangible asset) consisted of items that addressed ways in which participants exchanged tacit knowledge (e.g. sharing knowledge informally, mentoring, stories, brainstorming, and shadowing). This factor explains 13.10 per cent of total variance of the original variables. This result shows the breadth of tacit knowledge-sharing practices being used.

Training and development constituted the third factor, a tangible asset. This factor consisted of items on developing project manager competencies, support for PMP ${ }^{\circledR}$ certification, and a career path for project managers, as well as managerial support for training and development. This factor explains 12.54 per cent of total variance of the original variables. Similar to the project management maturity factor, this result exemplifies an investment in concrete project management practices.

The fourth factor, sharing know-what (another tangible asset), was evident through a set of items on concrete databases, systems, intranets, best practices databases, and processes for sharing knowledge. This factor included codified knowledge sharingpractices. It explains 11.92 per cent of the total variance of the original variables.

Undervalued sharing of know-how included items indicating that know-how was undervalued, not shared, or not supported widely. Know-how is not shared because it is perceived to be a source of power. This factor explains 7.33 per cent of the total variance of the original variables.

Undervalued sharing of knowledge consisted of items on the lack of knowledge sharing in general within the company, knowledge sharing taking place only within the team or department, and limited by time constraints. This factor explains 5.05 per cent of the total variance of the original variables.

In our conceptual model, we described the VRIO profile of the project management process (our dependent variable) as consisting of four characteristics - valuable, rare, inimitable, and having organizational support. We identified three factors in our exploratory factor analysis of the dependent variable:

(1) The latent construct of valuable consisted of nine items and had a Cronbach's Alpha of 0.929 .

(2) The latent construct of organizational support consisted of ten items and had a Cronbach's Alpha of 0.841 .

(3) The latent construct of rare consisted of three items and had a Cronbach's Alpha of 0.690 . management elements

611 
MRN

29,10

612
The fourth expected characteristic from the VRIO framework, inimitable, did not emerge as a factor. An item that describes project management as difficult to copy was, however, found included in the rare factor, leading to the conclusion that there is an overlap between these two, rare and inimitable characteristics. Table II shows the rotated component matrix for the dependent variable. Entries are bolded to clarify, which items load on a particular factor in Table II.

The factors, valuable, rare, and organizational support, explain 55.87 per cent of the total variance of the original variables, and this is a significant amount of variation explained.

The factor entitled valuable involved items that reflected project management's contribution to economic value (e.g. improving business performance, increasing profitability, and responding to environmental threats and opportunities). This factor explains 25.08 per cent of the total variance of the original variables.

The items that comprised the organizational support factor were those that reflected management support, adequate resourcing for the discipline, and project management as an organization-wide undertaking. In essence, organizational support reflects support to exploit project management as being valuable, rare, and costly to imitate. This factor explains 21.31 per cent of the total variance of the original variables.

The items that comprised the rare factor were those that showed project management to be unique, controlled by a few firms, and difficult to copy. This factor explains 8.69 per cent of the total variance of the original variables.

In assessing the six independent variable factors, we view the emergence of the second independent factor (sharing know-how) as a significant finding as it underscores the importance of tacit knowledge in a discipline where there is a focus on tangible factors and a prevalence of codified project management practices. We view this to be an important factor because we believe, as supported by the literature, that intangible assets (knowledge-based assets) contribute to competitive advantage (Teece, 1998; Ray et al., 2004; Sussland, 2001). In assessing the three dependent variable factors, our findings support the extant literature and the VRIO framework.

\section{Conclusion}

In this study, drawing from an online survey with North American Project Management Institute ${ }^{\circledR}$ members, exploratory factor analysis was used to examine the independent variables (tangible and intangible assets) and dependent variable (VRIO characteristics) of the project management process. We extracted three factors that represent tangible project management assets, three that represent intangible project management assets, and three that represent VRIO characteristics.

Our findings suggest that over and above the need for codified practices, a company should also consider intangible assets. Intangible assets are important because unlike codified practices they are not readily transferable or copied, and therefore, can be a source of a competitive advantage. Our findings also suggest a need for increased focus on knowledge sharing. Knowledge sharing emerged as a strong factor, both for codified practices and for tacit knowledge. However, companies represented in our sample undervalue sharing of project management knowledge, and in particular, sharing of tacit knowledge. Companies need to invest in assessing and improving their knowledge-based assets.

With projects increasingly being used to conduct work at both the operational and strategic levels of the firm, companies need to look to their project management process for sources of competitive advantage. This research is positioned as a step 
q10.1 Project management has helped us be better, faster, and/or cheaper in what we do

q10.2 Project management has increased our profitability q10.3 Project management has improved our overall business performance

q10.5 We use project management to provide better products/services

q10.4 Project management at my organization

significantly helps us respond to industry threats or opportunities

q10.6 Project management is a source of competitive advantage to my organization

0.748

q13.5 Rather than being able to trace our project management advantage to "one big decision" in our organization's past, our success can be...

q15.7 Our project management practices have improved year after year

q13.1 Organization that do not use project management the way we do, are at a cost disadvantage

q16.1 Our projects are adequately resourced with enough staff that is qualified to do the work

0.561

0.464

q16.2 Our projects are adequately resourced to manage them properly

q15.1 We are well-organized to practice project management at my organization with policies, procedures and routines q15.5 Executives at my organization are effective in their project management roles

q15.3 Project management is an organization-wide initiative

q15.6 We benchmark regularly to assess best practices in project management that could help us improve our practices

q15.2 Project management is important to our organization's mission q15.4 Executives at my organization have formal project management roles whereby they make project, program or portfolio q11.3 If $1 / 3$ of those that practice project management at my organization left tomorrow, project management would not change

q11.1 Many organization in our industry practice project management the way we do

q11.4 Relative to our competitors, project management at my organization is unique

q11.2 How we practice project management makes the practice unique at my organization

Notes: Extraction method: principal component analysis; Rotation method: varimax with kaiser normalization; Rotation converged in 6 iterations; Bolded entries in a column indicate items that load on the particular factor; Reverse coding was used on item q11.1
Table II.

Rotated component matrix of dependent variable 
MRN

29,10

614 towards heightened awareness and improved understanding of project management elements as strategic assets to support management practice.

The limitations of this study are acknowledged and addressed in our ongoing research. Whereas the sample size was fair and the Project Management Institute has a membership of over 270,000 (worldwide), the use of one membership mailing list represents an element of sample bias in terms of study generalizability. We plan to conduct the next survey with more than one membership mailing list. The study was also limited by the specifics of the instrument. Additional literature study and analysis of this database are underway to refine the instrument. For example, there is a clear need to specifically distinguish between the constructs of rare and inimitable through the use of more items.

This research adds to the growing body of strategy literature that builds on the resource based view of the firm. It is an important step towards analysis of the relationship between project management assets and the VRIO characteristics of the project management process. Our ongoing research in this area aims at an improved understanding of how the project management process can be a source of competitive advantage.

\section{References}

Amit, R. and Schoemaker, P.J.H. (1993), "Strategic assets and organizational rent", Strategic Management Journal, Vol. 14, pp. 33-46.

AoM (2005), A New Vision of Management in the 21st Century, in Aom (Ed.) Academy of Management, Honolulu, HI.

Barney, J.B. (1991), "Firm resources and sustained competitive advantage", Journal of Management, Vol. 17, pp. 99-20.

Barney, J.B. (1998), "On becoming a strategic partner: the role of human resources in gaining competitive advantage", Human Resource Management, Vol. 37, pp. 31-46.

Barney, J.B. (1999), "How a firm's capabilities affect boundary decisions", Sloan Management Review, Vol. 40, pp. 137-45.

Barney, J.B. (2002), Gaining and Sustaining Competitive Advantage, Prentice-Hall, Inc., Upper Saddle River, New Jersey.

Barney, J.B. and Zajac, E.J. (1994), "Competitive organizational behavior: toward an organizationally-based theory of competitive advantage", Strategic Management Journal, Vol. 15, pp. 5-9.

Castanias, R.P. and Helfat, C.E. (1991), "Managerial resources rents", Journal of Management, Vol. 17, pp. 155-71.

Castanias, R.P. and Helfat, C.E. (2001), "The managerial rents model: theory and empirical analysis", Journal of Management, Vol. 27, pp. 661-78.

Chakraborty, K. (1997), "Sustained competitive advantage: a resource-based framework", Advances in Competitiveness Research, Vol. 5, pp. 32-63.

Conway, J.M. and Huffcutt, A.I. (2003), "A review and evaluation of exploratory factor analysis practices in organizational research", Organizational Research Methods, Vol. 6, pp. $147-68$.

Couper, M.P. (2000), "Web surveys: a review of issues and approaches”, Public Opinion Quarterly, Vol. 64, pp. 464-94.

Couper, M.P., Traugott, M.W. and Lamias, M.J. (2001), "Web survey design and administration”, Public Opinion Quarterly, Vol. 65, pp. 230-53. 
DeFillippi, R.J. and Arthur, M.B. (1998), "Paradox in project-based enterprise: the case of film making”, California Management Review, Vol. 40, pp. 125-39.

Dillman, D.A., Sinclair, M.D. and Clark, J.R. (1993), "Effects of questionnaire length, respondentfriendly design, and a difficult question on response rates for occupant-addressed census mail surveys", Public Opinion Quarterly, Vol. 57, pp. 289-304.

Eisenhardt, K. and Santos, F. (2000), "Knowledge-based view: a new theory of strategy?", in Pettigrew, A., Thomas, H. and Whittington, R. (Eds), Handbook of Strategy and Management, 1st ed., Sage Publications, London.

ESI-International (2001), ESI-International. ESI International.

Fernie, S., Green, S.D., Weller, S.J. and Newcombe, R. (2003), "Knowledge sharing: context, confusion, and controversy", International Journal of Project Management, Vol. 21, pp. $177-87$.

Foss, N.J. (Ed.) (1997), Resources, Firms, and Strategies: A Reader in the Resource-based Perspective, Oxford University Press, Oxford.

Fowler, F.J. (1992), "How unclear terms affect survey data", Public Opinion Quarterly, Vol. 56, pp. 218-31.

Hartman, F.T. (2000), Don't park your brain outside: a practical guide to improving shareholder value with SMART project management, Project Management Institute, Upper Darby, Pennsylvania.

Hawawini, G., Subramanian, V. and Verdin, P.J. (2002), "Is performance driven by industry - or firm-specific factors? A new look at the evidence", Strategic Management Journal, Vol. 24, pp. 1-16.

Ibbs, C.W. and Kwak, Y.H. (2000), "Assessing project management maturity", Project Management Journal, Vol. 31, pp. 32-43.

Jugdev, K. (2003), "Developing and sustaining project management as a strategic asset: a multiple case study using the resource-based view", Unpublished $\mathrm{PhD}$ thesis. Project Management Specialization. University of Calgary, Calgary, AB.

Jugdev, K. (2005), "Project management as a strategic asset: what does it look like and how do companies get there?”, in Slevin, D.P., Cleland, D.I. and Pinto, J.K. (Eds), Innovations: Project Management Research 2004, 1st ed., Project Management Institute, Newtown Square, PA.

Jugdev, K. and Thomas, J. (2002), "Project management maturity models: the silver bullets of competitive advantage", Project Management Journal, Vol. 33, pp. 4-14.

Kaplan, S., Schenkel, A., Von Krogh, G. and Weber, C. (2001), "Knowledge-based theories of the firm in strategic management: a review and extension", MIT Sloan Working Paper no. 4216-01.

Kloppenborg, T. and Opfer, W. (2002), "The current state of project management research: trends, interpretations, and predictions", Project Management Journal, Vol. 33, pp. 5-18.

Kogut, B. (2000), "The network as knowledge: generative rules and the emergence of structure", Strategic Management Journal, Vol. 21, pp. 405-25.

Kogut, B. and Zander, U. (1993), "Knowledge of the firm and the evolutionary theory of the multinational corporation", Journal of International Business Studies, Vol. 24, pp. 625-44.

Koskela, L. and Howell, G. (2002), "The underlying theory of project management is obsolete", in Slevin, D.P., Pinto, J.K. and Cleland, D.I. (Eds), Frontiers of Project Management Research and Application, Project Management Institute, Seattle, Washington.

Lesser, E.L. and Storck, J. (2001), "Communities of practice and organizational performance", IBM Systems Journal, Vol. 40, p. 831.

\section{management elements}

Project

615 
MRN

29,10

616

Lopez, V.A. (2001), "An overview review of the resource-based view (RBV) of the firm, drawing on recent Spanish management research", Irish Journal of Management, Vol. 22, pp. 105-20.

Mata, F.J., Fuerst, W.L. and Barney, J.B. (1995), "Information technology and sustained competitive advantage: a resource-based analysis”, MIS Quarterly, Vol. 19, pp. 487-507.

MicroFrame (2001), Project management maturity model. Business Engine: Micro Frame Technologies and Project Management Technologies Inc.

Montealegre, R. (2002), "A process model of capability development: lessons from the electronic commerce strategy at Bolsa de Valores de Guayaquil”, Organization Science, Vol. 13, pp. 514-31.

Nonaka, I. (1994), “A dynamic theory of organizational knowledge creation", Organization Science, Vol. 5, pp. 14-37.

Nunnally, J.C. (1978), Psychometric Theory, McGraw-Hill, New York, NY.

Packendorff, J. (1995), "Inquiring into the temporary organization: new directions for project management”, Scandinavian Journal of Management, Vol. 11, pp. 319-33.

Project Management Institute (2004), A guide to the project management body of knowledge $\left(\mathrm{PMBOK}^{\circledR}\right.$ Guide), Project Management Institute, Newtown Square, Pennsylvania.

Ray, G., Barney, J.B. and Muhanna, W.A. (2004), "Capabilities, business processes, and competitive advantage: choosing the dependent variable in empirical tests of the resourcebased view", Strategic Management Journal, Vol. 25, pp. 23-37.

Rumelt, R.P., Schendel, D.E. and Teece, D.J. (1994), "Fundamental issues in strategy", in Rumelt, R.P., Schendel, D.E. and Teece, D.J. (Eds), Fundamental Issues in Strategy, Harvard Business School Press, Cambridge, Massachusetts.

Sussland, W.A. (2001), "Creating business value through intangibles", Journal of Business Strategy, Vol. 22, pp. 23-8.

Tabachnick, B.G. and Fidell, L.S. (2000), Using Multivariate Statistics, Harper Collins College Publishers, Northridge, CA.

Teece, D.J., Pisano, G. and Shuen, A. (1997), "Dynamic capabilities and strategic management”, Strategic Management Journal, Vol. 18, pp. 509-33.

Teece, D.J. (1998), "Capturing value from knowledge assets: the new economy, markets for knowhow, and intangible assets”, California Management Review, Vol. 40, pp. 55-79.

Ulri, B. and Ulri, D. (2000), "Project management in North America: stability of the concepts", Project Management Journal, Vol. 31, pp. 33-43.

Wiggins, R.R. and Ruefli, T.W. (2002), "Sustained competitive advantage: temporal dynamics and the incidence and persistence of superior economic performance”, Organization Science, Vol. 13, pp. 82-104.

Zahra, S.A. and Nielsen, A.P. (2002), "Sources of capabilities, integration, and technology commercialization”, Strategic Management Journal, Vol. 23, pp. 377-98.

\section{About the authours}

Kam Jugdev is an Associate Professor of Project Management and Strategy in the MBA program at Athabasca University in Alberta and an Adjunct Professor at the Schulich School of Engineering, University of Calgary, Alberta. Her specific areas of interest and research include project management as a source of competitive advantage, project lessons learned, project management maturity models, project success/failure, project management education, and distance education. Dr Jugdev actively contributes to the advancement of academic and 
professional communities of management practice. Kam Jugdev is the corresponding author and can be contacted at:kamj@athabascau.ca

Gita Mathur is an Associate Professor in the Department of Organization and Management in the College of Business at San Jose State University. Her research interests are in the management of technological innovation and product and service development processes. She has held engineering and management positions in the semiconductor industry and has served as a management consultant to several technology-based companies. She holds a Ph.D. in electrical engineering from Rensselaer Polytechnic Institute, Troy, New York and a DBA in technology and operations management from Harvard Business School, Boston, Massachusetts.

\section{Project \\ management \\ elements}

617

To purchase reprints of this article please e-mail: reprints@emeraldinsight.com Or visit our web site for further details: www.emeraldinsight.com/reprints 